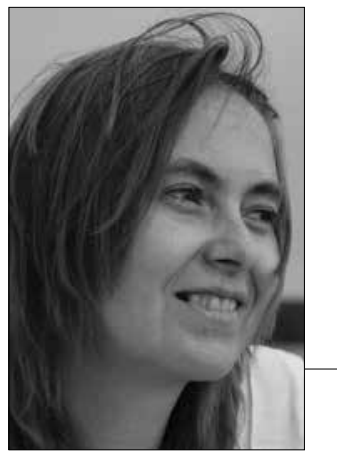

https://doi.org/10.24101/logos.2018.67

Gauta 20181029

\title{
SALOMĖJA JASTRUMSKYTE்
}

Lietuvos kultūros tyrimų institutas, Lietuva

Lithuanian Culture Research Institute, Lithuania

\section{OKULIARCENTRISTINĖS ESTETIKOS ATVERTYS IR GRIZŽTYS: AKIS IR LOBYNAS \\ Discovering and Rebounding the Ocularcentristic Aesthetics: An Eye and a Treasure}

\author{
SUMMARY
}

The article is devoted to the conceptual and historical analysis of the eclipse of ocularcentristic aesthetics and to the opening of opportunities for the present visual aesthetic discourse of visual culture. The text highlights two main opportunities for the development of ocularcentristic aesthetics - such as eye apologetics and mistrust, denial and contempt. The analysis of specific examples of art history and analysis of aesthetical perceptions shows that the different parts of the human sensorium, which make up a complete multisensory tissue, become a consequence of the fluctuation of this bipolar phenomenon. From here, the distrust of the pre-eminence and supremacy of the eye, which is most noticeable in French aesthetics and art philosophy, has emerged in modernist consciousness. In the long run, it also spread to the English and German speaking countries, reaching the epoch of the 20th century, when the French philosophical doubts were fruitfully taken over by American art philosophers; in turn, the unpredictability of the eye was already overwrought by modern art and became the self-image of the current post-modern visual culture and aesthetic and artistic consciousness.

\section{SUMMARY}

The article is devoted to the conceptual and historical analysis of the eclipse of ocularcentristic aesthetics and to the opening of opportunities for the present visual aesthetic discourse of visual culture. The text highlights two main opportunities for the development of ocularcentristic aesthetics - such as eye apologetics and mistrust, and even denial and contempt. According to the analysis of specific examples of art history and analysis of aesthetical perceptions, the article shows that the different parts of the human sensorium, which make up a complete multisensory tissue, become more and more as a consequence of the fluctuation of this bipolar phenomenon. From here, the distrust of the pre-eminence and supremacy 
of the eye, which is most noticeable in French aesthetics and art philosophy, has emerged in modernist consciousness. In the long run, he also spread to the English and German speaking countries, reaching the epochs of the 20th century. in the middle of the year, when the French philosophical doubts have been fruitfully taken over by American art philosophers; in turn, the unpredictability of the eye was already overwrought by modern art became the self-image of the current post-modern visual culture and aesthetic and artistic consciousness.

$\mathrm{O}$ kuliarcentrizmas yra sąvoka, vartojama norint apibūdinti paradigmą ar epistemologija pagrịstą vizualinèmis ar okuliarinèmis metaforomis. Tai Vakarų filosofijos tradicija, kurioje žinojimas, tiesa ir tikrovè interpretuojami rega kaip pagrindiniu mąstymo ir tikrovès suvokimo instrumentu. XVIII a. pabaigos racionalizmą galima laikyti modernaus okuliarcentrizmo išeities tašku, juolab kad aptariamajij laikotarpi apibūdinantis Apšvietos pavadinimas regą nurodo kaip esminę pažinimo sąlygą. Ši paradigma vis dar rymo socialiniuose ir gamtos moksluose, nors ji stipriai krečiama filosofuc, socialinių, politikos mokslų teoretiku, tiek ir meno, estetikos, kultūros, lyginamųju civilizacijų tyrinètojų kritikos.

Be to, pats okuliarcentrizmas yra ne tik apklausiamas ivairiais aspektas. Nors būdamas Vakarų kultūros struktūriniu karkasu, jis nèra vienalytis kaip ir jo kritika. Pavyzdžiui, Donncha Karavanaghas siūlo tris okuliarcentrizmo kritikos plotmes, parodančias jo vidinę dinamiką ir potencialias atvertis kritikai: išplèsto (extended), perkelto (displaced) ir apversto (inverted) okuliarcentrizmo kritines strategijas (Karavanagh 2004: 446). Visose minètose pozicijose dominuoja prancūzú, vokiečių ir amerikiečių filosofai, sukuriantys savitą okuliarcentrizmo eksperimentinį lauką nuo neigimo išplečiant pati okuliarcentini mąstymą iki kraštutinių jo ribų - šią strategiją puikiai pa- naudoja tiek romantizmo filosofija, kritikuojanti Apšvieta, taip pat Friedricho Nietzsche's, tiek postmodernistinis kontravizualumas su Jacques'o Derrida filosofija kaip fotologija (Derrida 1978: 27) ir Michelio Foucault galios supervizualumu. Perkelto okuliarcentrizmo kritinè strategija veikia ikkeliant $\mathfrak{i}$ akies centrinę poziciją kitas jusles, daugiausia klausos ir lytos, kitaip tariant, procesualias jusles. Joje sutinkame ir Henri Bergsona ir Martiną Heideggeri, ir Hans-Georgo Gadamerio hermeneutika, Jürgeno Habermaso „balso diskursą" bei amerikiečiu pragmatistą Richardą Rorty, kreipusi filosofini diskursą nuo teorijos link naratyvo, kitaip tariant, metaforiškai pasisukant nuo regos prie klausos. Galiausiai okuliarcentrizmą galimą kritikuoti tiesiog apverčiant modernistinę okuliarcentrizmo schemą, implikuojančią gryno teorinio regejjimo ir negrynos praktinès vizualiosios tikrovės dichotomijos apvertimą pabréžiant, jog pati rega yra tapusi negryna mediju ir marketingų chaose. Ši pozicija Karavanagho tyrime atrodo sąlyginè, nes jai priskirtą Jean'ą Baudrillardą puikiai galètų paremti ir Slavojus Žižekas. Vis dèlto galima sakyti, kad visi šie okuliarcentrizmo falsifikavimai apklausiant jo stabilumą nėra galutiniai, nes vienaip ar kitaip yra grižtama i pradini tašką - pati okuliarcentrizmą apklausianti kalba neatplèšiamai rymo ant okuliarinių metaforų. Vis dèlto ši kritinè 
okuliarcentrizmo apgultis yra nuostabiai naudinga Vakaru estetikos pokyčiams, vedantiems link jusliu vienovès ir pastarosios igalinimo patiriant tikrovę ir artefaktus.

Taigi, regos hegemonija Vakaru kultūroje buvo pirmiausia apklausta jau Friedricho Nietzsche's ir Henri Bergsono filosofijoje, o menininkai, kaip antai Stephane'as Mallarmé ir Paulis Cézanne'as, savo kūryba dar labiau sustiprino ši procesa, kaip, beje, ir Pirmasis pasaulinis karas, kurio poveiki net tokiems paradigminiams pokyčiams, kaip okuliarcentrizmo užtemdymas, tik pastaruoju metu imama nuosekliau tyrinèti ir ivertinti. Antikinis skopinis režimas, kitaip dar vadinamas karteziniu perspektyvizmu, XX a. prarado savo lyderio vaidmeni, o netrukus ir pačios okuliarcentrizmo premisos taip pat tapo kvestionuotos, teigia Martinas Jay (Jay 1991: 15). Ypač didelè abejonių dèl vyraujančių regos konstrukcijų mąstyme ir kultūroje santalka pasirodè tarpukario Prancūzijoje, kur daugybe i̇vairiu sričiu intelektualu skelbė prarandą pasitikèjimą rega.

Su tam tikromis išlygomis Vakaru kultūrą galima apibūdinti kaip okuliarcentristinę paradigmą, pagrịstą regos kuriama, visiocentrine žinojimo, tiesos ir tikrovès interpretacija. Be abejo, daugiausia okuliarcentristinès paradigmos kūrimuisi padejjo Platonas, Descartes'as ir Apšvietos laikotarpio mąstytojai. Beje, Platono mąstyme brèžiama aiški demarkacinè linija tarp fiziniu akių regos ir „proto akies“. Iš esmés okuliarcentrizmas yra nepaliaujama žaismè tarp šiu dviejų skirtingų "akių“ (Karavanagh 2004: 447). O Merleau-Ponty savo knygoje L'CEil et l'esprit teigia „esant trečią aki, kuri regi nutapytus paveikslus ir netgi mentalinius vaizdinius (MerleauPonty 1964). Nors Platono nepasitikejimas fizine akimi lèmé jo abejingumą ir šaltumą visiems mimetiniams menams, kuriuos laikẻ apgaulès forma, o vèliau prieštaringą nepasitikejjimą optikos keliamomis iliuzijomis greta su optinio regos mechanizmo garbinimu sutiksime René Descartes'o filosofijoje ir jo veikale Dioptrique (1637), būtent meno ir estetikos srityje okuliarcentrizmo paradigmos siūbavimas ir nestabilumas taps akivaizdžiausias jau nuo XX a. pradžios.

Dauguma esminių Apšvietos sąvoku, kaip antai objektyvizmas, refleksija, kritiškas racionalumas ir subjektyvizmas, yra fundamentaliai atremtos i regos pirmenybę. Antai Hanso Johnas (1966) manymu, rega yra vienalaikiškumo pojūtis, leidžiantis apimti plačią teritoriją vienu momentu, o klausa yra laikiškesnè ir joje susipina praeitis, dabartis ir ateitis i vieną reikšmingą visumą. Be to, „rega, kitaip nei klausa, palieka vizualu neužbaigtą jo paties veiksmu, sukurdama unikalų kitokybès pojūtí. Maža to, nutolinimo fenomenas, kuris yra esmingiausia regos funkcija ir savybè, padeda sukurti įsitikinima, kad objektai yra nutolę ir neutraliai priimami suvereniu subjektu, o tai savo ruožtu grindžia subjekto-objekto dualizmą būdingą graikiškajai ir Vakaru metafizikai (Karavanagh 2004: 448). Nors ši spektatoriška epistemologija išliko dominuojanti Vakaru filosofijoje, ji buvo smarkiai kritikuojama daugelio filosofuc visą XX a. iki dabar. Tarp svarbiausiu ir nuosekliausiu okuliarcentrizmo kritikai skirtu darbu reikètu paminèti Hanso Jonaso (1966), Davido Levino (1993; 1997), Martino Jay 
(1993) ir kt. Taip pat Davido Howes'o (1991; 2010), Constance Clasen (juslių istorijai skirtus) veikalus.

Taigi okuliarcentrizmo estetikos aktualejimas po tokio ilgo ir laipsniškai augusio akies privilegijuoto vaidmens neigimo atrodo išties paradoksaliai. XX a. pradžioje, ypač po Pirmojo pasaulinio karo, pastebimas stiprus nusivylimas rega, nes realybė ir jos sukrèsta žmogaus sensorika pateikia kraštutinius regos paniekinimo, jos intencionalaus sunaikinimo pavyzdžius, kaip antai Georgeso Bataille'o kūryboje besikartojanti iš karo lauko apokaliptiškai sensorinès patirties parsinešta kraštutinè okuliarcentristinès dimensijos ištiktis - viską apimantis žydras dangus ir akinanti šviesa (Jay 1991: 17). Tačiau dabartinëje XXI a. kultūrinëje situacijoje susiduriame su žmogaus sąmonès ir būties medijavimu per gryniausios vaizdinijos proverži, pasisavinanti naujausias technologijas itin paveikiems ir ìspūdingiems regimosios patirties klodams kurti. Martinas Jay, vienas žymiausių šių dienų okuliarcentrizmo epistemologijos istorikų ir kritikų, tik užsimena apie tai, jog mūsų dabarti pasiekia XX a. akies paradigminio užtemdymo rezultatai, kurie tik pradeda atsiskleisti. Jay nubrèžia okuliarcentrizmo trajektoriją per jaučio akies skrodimo momentą Descartes'o Dioptrique, siurrealizme (Luisas Bunuelis ir Salvadoras Dali Un chien Andalou), nesvarbu, ar jis būtų suprantamas André Bretono ar Bataille'o terminais, kaip centrinį epizodą laipsniškame akies, kilniausiosios iš juslių, pažeminime, kurio visos pasekmés [kursyvas - S. J.] tik dabar ateina ir tampa suvokiamos mūsu dienomis (Jay 1991: 31).
Tačiau XXI a. pradžioje susidurdami su triumfuojančiu regos atsinaujinimu, beje, daugiausia estetinėse plotmėse, šias pasekmes galime svarstyti kaip ambivalentiškas. Tikètina, jog intensyvus antiokuliarcentrizmas tebuvo viena pačios regos hegemonijos implikaciju, tam tikras jos tvarumo ir tęstinumo eksperimentas. Nusivylimas rega ar atsivėrimas jai hedonistišku patiklumu - nuolat vienas kitą keičiantys dydžiai Vakarų kultūroje. Jokios sensorinès patirtys nèra kultūrinè aksioma, jos kinta kartu su pačia kultūra, jos svyruoja mentalitetú vëjuose. Regos juslès ir kaip pagundos (palyginkime kad ir Augustino „akiu geismo" negatyvią sampratą bei Baudrillardo veikale La séduction (1979) rafinuotai pateiktą okuliarcentristinių pagundu kritiką), ir kaip sukrètimo (trauminių Pirmojo pasaulinio karo patirčių paveiktas siurrealizmo gimimas, psichoanalitinis simptomo vizualumas, technologiju, kaip antai fotografijos, kino, pagaliau rentgeno, vizualinio pertekliaus sukeltas nesaugumo jausmas) vieta lemia iki XX a. pabaigos besitęsiančią intelektualinę akies vivisekciją. Ir štai XXI a. pirmaisiais dešimtmečiais pakyla nauja okuliarcentrizmo banga. Nors jos tyrimas nèra šio straipsnio tikslas, tačiau jos identifikavimas patvirtina netolygu ir iki dabar besitęsiantị okuliarcentristinès paradigmos dinamiškuma, nuolatinius svyravimus, kurių amplitudè dar nèra kultūros iki galo atrasta. Okuliarcentrizmo permanentinè dinamika yra problema, kurios nepastebi tiek jo apologetai, tiek kritikai susitelkdami tik i vieną šios paradigminès ašies posvyrio kampą. Šiame straipsnyje, pasinaudodami juvelyrinio dirbinio 
ir jo gausos, t. y. lobyno, metafora atskleisime estetinę properšą į okuliarcentrizmo nepastovuma, kitaip tariant, jo nepaliaujamai besiblaškančią vertės kismo vèliavą. Ši yra imanentinè Vakaru kultūros dalis, kurią taip klaidingai esame linkę laikyti homogenišku monolitu.

Šio tyrimo kontekstui įdomi Isis Brook fenomenologinė okularcentrizmo kritika remiasi Maurice'o Merleau-Ponty ir Walterio Ongo paviršiu teorija. Jos manymu, okuliarcentrizmas yra terminas, išreiškiantis visai Vakarų kultūrai būdingą išskirtinę regos juslès poziciją. Vienaip ar kitaip sutariama, jog okuliarcentrizmas yra Vakaru kultūros kūrinys ir atrama. Kitos juslès, kaip antai uoslè, lyta, kinestetinis patyrimas ir netgi klausa, nelaikomos vertingomis kaupiant tikrovès pažinimą.

Tačiau Walteris Ongas savo originalioje okuliarcentrizmo kritikoje pabrěžia tokiai intelektualinei teritorijai priklausančios regos polinki bet koki vidu versti paviršiais, t. y. išore, ir iš to kylančias implikacijas (Ong 1967: 74). Nors okuliarcentrizmo tvirtovę Vakaru kultūroje pastato Platonas ir Aristotelis, o vèliau jų idèjos pateko į viduramžiu scholastinị mąstymą ir ankstyvojo Renesanso tekstus, tačiau jau viduramžiais regos pirmumas visų juslių atžvilgiu buvo pamintas ir beveik sunaikintas susikuriant daugiasluoksnei vidiniu Dievą patiriančiu juslių doktrinai, kuriai pradžią davė Origeno apmąstymai apie riboto žmogiškojo juslyno ir dieviškojo pažinimo prieštaringumą. Galiausiai viduramžiais visos žmogiškos juslès kaip visuma (taip pat ir rega) buvo nuvertintos kaip žyminčios gyvūniškajji, o ne dieviškajji žmogaus pradą. Regos pojūtis bus apkumš- čiuotas ir Augustino asketika apie „akiu geismą" - jam, beje, gražiai pritaria, tik su priešinga konotacija, siurrealizmo tèvas André Bretonas: „kiek akys aprépia, visur yra geismo atkūrimas" (Breton 1987: 15). Jei žvelgtume į okuliarcentrizmą kaip ì vieningą Vakarų kultūrą užklojantį koncepta jis būtų itin netolygus. Grižtant prie mūsų temos apie juvelyrini puošnuma, lobio metafora nebuvo vien regos metafora, net jeigu būtent tauriưjų metalu ir brangakmenių puošnumu bažnyčių altoriuose būdavo išreiškiama vizualinè teologijos ekstazè. Rega vis tiek yra juslè, ir kaip juslè geriausiu atveju gali būti jei ne nuodèminga, tai bent apgaunanti. Tačiau su „monastinio asketizmo pabaiga ir užburiančia mokslo galia rega igyja, tegul ir ne kilniausiosios juslès, bet vis dèlto naują epogèju" (Brook 2002: 69).

Tačiau net paties René Descartes'o, Vakarų okuliarcentrizmo vieno iš patriarchų, vaidmuo nužeminant kitas jusles ir iškeliant okuliarcentrizmą yra painus. Jo cogito rymo ant mąstymo eksperimento, kai jis teigia: „Aš turéčiau svarstyti save kaip neturinti nei ranku, nei akių, nei kūno, nei kraujo, nei jokio pojūčio" (Descartes 1973: 148). Tačiau regos pagarbinimas mokslo naudai, pasirodęs jo veikale Dioptique, yra aiškus. Kartezinis protas (ypač Johno Locke'o interpretacijos, skirtos proto apmąstymui) stebi pasauli vidiniame ekrane, o būtinas minties modeliavimas pagal regą yra Apšvietos projekto kulminacija. Vien tik regos jusle tegalinti pasakoti apie pasauli nustumdama i pakrašti kitas jusles. Tačiau „vadinamasis pažistančiojo proto regëjimas yra vienaakis, aklas spalvoms, netekęs gylio ir spalvos potyrio“ (Jay 1991: 69). 
Todèl Walterio Ongo požiūris ì okuliarcentrizmo pagrindą - abstrahuotą regos juslę - yra griežtas: rega atveria vien tik paviršius. Ji niekada negali įsiskverbti $\mathfrak{i}$ vidu ir nuolat traktuoja bet kokị vidaus atvėrimą kaip dar vieną paviršių. Ji niekada negali išeiti kitapus paviršių (Ong 1967 :74). Isis Brook šia ižvalga remiasi kaip fenomenologinès okuliarcentrizmo kritikos išeities tašku (Brook 2002: 68).

O juk ir lobis, jo dedamoji - juvelyrinis dirbinys, yra ne tik regimi ir atstumą nuo reginčiojo palaikantys paviršiai, bet ir dalyvauja kūno judejjime, stimuliuoja jusles - lyta, jos tekstūrinius ir temperatūrinius pojūčius, pagaliau netgi pati rega, susidurdama su aukso ir brangakmenių švytëjimu, fiziologiškai būna apakinama, ši apakimą tiek mistikų patyrimuose, tiek simbolizmo ir romantizmo sugestijose įvardijant kaip ypatingą estetini aukšti susiliejant su dievybe arba patiriant grožio ribas. Taigi regą kvestionuoja tai, kas ją stimuliuoja. Čia galètume rasti ir Kavanagho tezès apie okuliarcentrizmo inversiją tęsini, kaip antai Jean'as Baudrillardas, Gianni Vattimo, Guy Debordas okuliarcentrizmą iš vertikalaus sociopolinio ir gamtamokslio olimpo perkelia i horizontalią postmoderniuju laikų konsumeristinę estetiką ir elektronini panoptikoną (Kavanagh 2004: 459). Būtent čia skleidžiasi ne tik geidulingi tūkstantlapiai delioziški paviršiai, bet tiesiog atbukusios, neskaidrios, stabo ištiktos arba tarsi valkčiu aptrauktos, tačiau be paliovos geidžiančios regèti vis daugiau akies snūduriavimas.

Beje, postmoderniuoju laiku ịvykę juvelyrikos meno pokyčiai nusigręžè nuo autentiško brangiưjų medžiagų blizgesio jas pakeisdami arba dirbtinèmis medžiagomis, kurios žèri, arba tą žèresi ironizuoja, arba galiausiai naudojamos asketiškajj estetiškumą palaikančios matinès, blyškios, netgi organinès ir objektyvios medžiagos. Rega tarsi nori nusigręžti nuo juvelyrinio paviršiaus atsisakydama ir natūralių ją neigiančių medžiagos savybių pliūpsnių arba haliucinaciškai besimègaudama ju pigumu ir laikinumu (pigios spalvotos folijos, Svarovskio kristalai ir kt.).

Rega nuolat balansuoja ant savęs neigimo - galbūt tai yra natūralus Vakarų okuliarcentrizmo bruožas, jo viena iš emanaciju, kuriomis tuomet galima laikyti ir antiokuliarcentristini George'o Battaile'o minties šèlsmą ar Sartre'o šaltą atgrasą regai. Georges'o Bataille'o Historie de l'Oeil (Akies istorija), išspausdinta mažu privačiu 134 kopiju tiražu ir pseudonimu, niekada nebuvo daugiau publikuota Battaile'ui esant gyvam. Tik 1967 m. šis kūrinys tapo plačiai svarstoma klasika ir îkvèpė Rolando Barthes'o, Michelio Foucault, Susan Sontag ir daugybès kitu mąstytoju interpretacijas. Regos kaip šviesos (saulès) pakeitimas irimu ir puvėsiais veikiau buvo tik oziriškasis okuliarcentrizmo atmirimas. Apšvietos supūdymas Bataille'o perversijose negalejo sukelti aukso, kaip ir tos pačios jo neigtos saulès, entropijos. Apšvietos entropijos neįmanomumas akivaizdžiai parodytas daugialype, tačiau veikiai kapituliuojančia okuliarcentrizmo kritika, vos tik naujausia pasaulio technologinè apyvoka susijungia su kontrole, statusu ir užkariavimu plačiausiomis prasmėmis. Okuliarcentrizmo grižimą sveikina ir nemažai šiuolaikinių mąstytojų. 
Taigi regos juslès absoliutumu ir pirmenybe kitų juslių atžvilgiu daugeli amžių buvo abejojama, ir galiausiai XX a. jie buvo smarkiai paneigti, bet XXI a. regos juslè vèl daugiausia pakeitè kitas komunikacijai ir estetiniam gèrèjimuisi skirtas jusles, net jei šios jau buvo spejusios išvešèti ir apsirūpinti technologine mediacija. Nors apie juvelyrini dirbini kaip apie regos juslès apologetiką kalbèti galima daugeliu aspektu, ši kartą paliekame nuošalyje Aldous'o Huxley'o ir viduramžiu mistikų perkeistos tikrovès regejjimus, kuriuose aukščiausi jusliniai transcendencijos patyrimai buvo išreiškiami juvelyrinio lobio regimosiomis metaforomis. Tačiau mums vis dèlto tenka atkreipti dèmesi, jog juvelyrinis dirbinys pats savaime nèra tik dar viena daiktiškumo hipostazè. Ypatingi juslinès patirties, socialinio statuso, estetinio tobulumo superliatyvai daugelyje epochuc tiek Vakaruose, tiek Rytuose buvo susieti su brangiųju metalų, retųjų mineralų ir išskirtinių žmogiškosios vaizduotės formų dariniais. Taigi juvelyrinis dirbinys, lobis yra ypatinga tiek Vakaru, tiek Rytų estetikai būdinga regos apologetikos vizualinè metafora.

Akinančio grožio brangenybių lobis buvo regimas, geidžiamas ir reprezentuojamas visose epochose, jis tapo tiek estetikos, tiek XX-XXI a. juvelyrinio lobyno samprata. Pačios juvelyrikos estetika Vakaruose iš esmès keitèsi, siekta ne tik perstumdyti antropologines bei juslines konstantas, bet ir menu sandaros permainų. Juvelyrika èmé balansuoti tarp tikslinio puošybinio meno bei sau pakankamo, savirefleksyvaus konceptualaus meno statuso. Taip išskirtinè meno niša ėmè prarasti savotišką kitos, aukštesnès tikrovės mąstymo instrumento ir estetinio patyrimo etalono rangą. Kita vertus, regos aukštasis statusas abiem juvelyrikos meno atvejais išlieka beveik tas pats - transcendentinèmis ekstazèmis apsemta meno sritis pasitenkinimą ir šlovę visu pirma teikia akims. Taip juvelyrinis dirbinys tampa materialiai apčiuopiamu okuliarcentrizmo argumentu.

Štai iš to kylantis neiprastas teiginys: didžioji dalis juvelyrinio dirbinio istorijos, sakytume, juslinès brangenybiu istorijos, yra tiesiogiai susijusi su rega, lygiai kaip su ja susijusi Rytu, ypač Egipto, hebraju, Indijos, arabų musulmoniškojo pasaulio, o vèliau egiptiečiu, hebrajų ir islamo estetikos tradiciju paveikta Vakarų estetika. Tik regos ir juvelyrinio papuošalo saitai čia labai saviti, nes brangus juvelyrinis dirbinys dažniausiai suvokiamas kaip spindintis grožis par exellence, tai tarsi onotologinès sinestezijos apraiškos, kai net kitose meno šakose, net religijoje, mitologijoje aukščiausią groži linkstama išsakyti lyginant su tauriaisiais metalais, brangakmeniais ir perlais, bet jau ne kaip neorganinès gamtos dalimi, o kūrybinio veiksmo apdorotais artefaktais. Tačiau aukso blizgesys yra lygiai taip pat akinantis kaip ir agresyvi, aki kastruojanti Bataille'o saulè.

Iš tiesų būtų labai įdomu ištirti, nors tyrimo apimtis toli pranoktų mūsų teksto užmoji, šią juvelyrinio dirbinio ontologinę sinesteziją îvairiose civilizacinèse ir kultūrinèse erdvėse ir šio estetinių problemų lauko sąsajas būtent su regos jusle. Nors rastume aukso ar sidabro spindesi, deimantų ir rubinų îvairiomis spalvomis spindinčių briaunų aštrumą XIX a. simbolizmo poezijoje, bet dar gausiau rastume auksinių ir deimantinių vizijų Vakarų viduramžių teologiškojoje estetikoje 


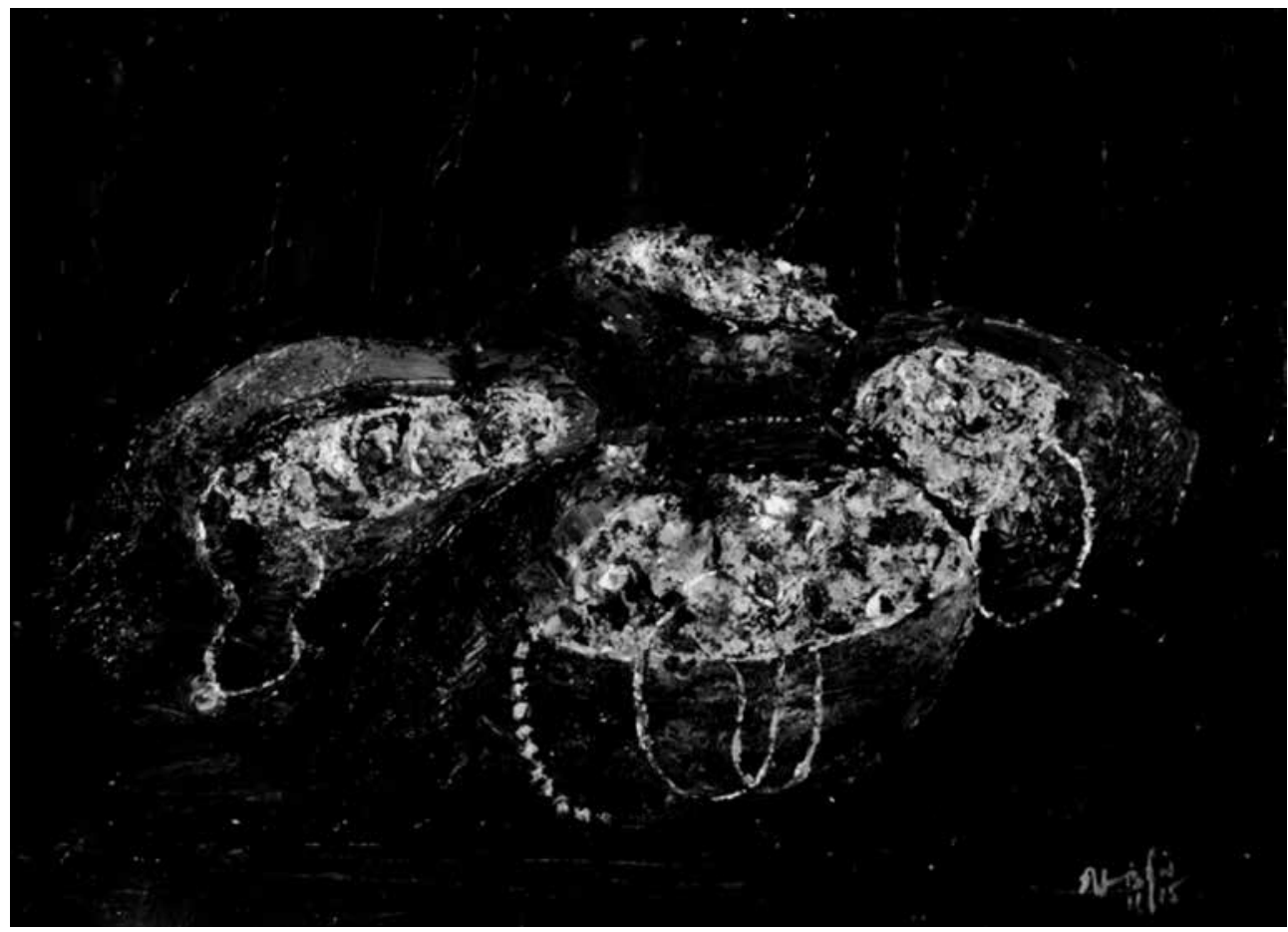

Senthil Kumar. Lobis, 2015 m. Drobė, akrilas

(pvz., Umberto Eco Arte e bellezza nell' estetica medievale, 1987), o dar gausiau šviesos ir spindesio estetikoje, tegul ir kitaip artikuliuotoje, senovès Indijoje, Senovès Egipte. Atsivertų dar beribiškesnis tyrimo laukas, jei apimtume vadinamąją kasdienybės estetika, kurioje dabartiniai Cartier papuošalai lygia greta su Liudviko XIV estetiniu pertekliumi užplūstų aki žèrèjimu ir... atstumu.

Veikiausiai bus netikèta, bet Bulough estetinio nuotolio sąvoka, grynų gryniausia antikinio regos prado kaip atstumą steigiančios juslès apologetika, kuri tokia paranki ne tik menui, bet, tarkim, ir BBC ar Youtube vaizdinijai, idealiai atskleidžia papuošalo kaip regimo daikto vietą tarp kitų daiktų. Juvelyrinis dirbinys, telkdamas savyje transcenden- cijos rudimentus, galios tvarumą ir hierarcijos nuosekluma, nesąmoningai verčia kasdieniame komunikacijos akte atsitraukti. Rega, tarpininkaudama tarp juvelyrinio dirbinio ir sociumo, kuria ne tik aiškiai apibrèžtas atskirtis - ekonomines, genealogines, pagaliau, anot Jeano Gebserio, maginiam sąmonès sluoksniui priklausančias iracionaliąsias, - bet labai tiesiogiai papuošalas kaip regimas arba regimoji juvelyrika steigia ypatinga santyki sociume, kuriame yra pagarbos, atsitraukimo, adoravimo, subordinacijos ir kitų santykių rudimentų. Galiausiai juvelyriniai dirbiniai kai kuriuose meno žanruose, įsitvirtinusiuose siužetuose (pvz., vanitas paveikslai) ir kt. simbolizuoja akių šviesą = gyvenimą ir iš to besirandanti laikinumą ir tuštybę. 


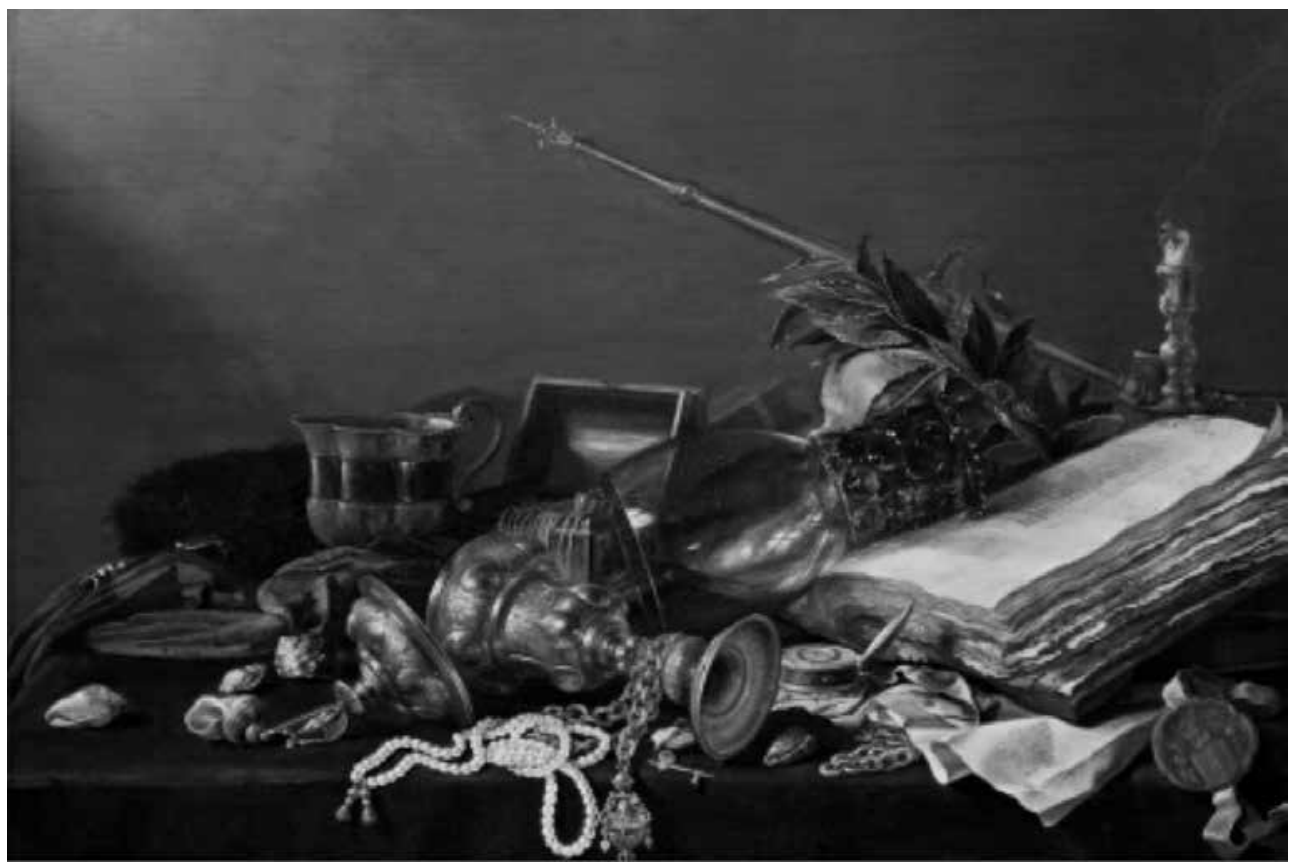

Pieter Claesz. Vanitas natiurmortas, 1630 m. Aliejus, lenta

Taigi ar jis būtų skirtas dèvèti, t. y. turintis paskirti, ar gèrètis kaip esencialiu menu be kontakto su kūno paviršiais, abu šie vektoriai vis tiek susitinka regoje, kur juvelyrinis dirbinys tampa žmogaus steigties ir veiklos riboženkliu. Dar stokojama juvelyrinio dirbinio ontologinių apmąstymų, o antropologiniai kol kas skęsta empirikoje, tačiau akivaizdu tai, jog regos juslè specifiniu būdu steigia juvelyrinio darinio ontologini pamatą ir dialektiškai būtent juvelyriniame dirbinyje geba išvengti neramios kultūrinio apklausimo jūros. Taigi okuliarcentrizmo lobynas išties yra dialektiškas - ypatinga grožio koncentracija (o grožis juk yra tai, kam nereikia argumentu, anot Arthuro Danto), juvelyriniu dirbiniu lobyne besigèrinti akis pati sau suranda prieglobstị, kuriame tarsi suteka i savo deltą. Re- ga tampa lobiu žvelgdama ị lobį. Danto jau šiame amžiuje parašytoje savo knygoje The Abuse of Beauty: Aesthetics and the Concept of Art (Danto 2003), savitai paneigdamas savo antiesencialistines meno teorijas, kuriomis sukrètè meno pasauli 8-ajame dešimtmetyje, aukština groži, psichofiziologiškai perpildanti žmogaus patyrima; akis vèl tampa grožio orbitos centru.

Nors modernizmo epochoje lygiagrečiai kvestionuojamam visiocentrizmui sparčiai plètojosi ir naujos garso bei klausos sampratos, formavosi specifinè modernistinè akustinė erdvè, atverianti kitu juslių bei jų sampynų estetinę vertę, tačiau šiuo atžvilgiu Martinas Heideggeris skeptiškai teigia, jog mūsų tiek regos, tiek klausos autentiška geba nyksta dèl radijo ir kino technologiju itakos (Hei- 
degger 1977: 48). Maxas Horkheimeris, nors labiau atstovaujantis audiocentrinei paradigmai, taip pat $\mathfrak{i}$ garso ir vaizdo technologijų pažangą žvelgia kaip ì klausos ir regos destrukciją (Horkheimer 1978: 162). Iš tiesų modernizmo laikotarpis susiduria su esminiu sensoriniu paradigmu judesiu, ir būtent regos lyderiaujančios pozicijos ginčyjimu stiprejjančia klausos ittaka. Taigi ar negresia vienos - regos - hegemonijos pakeitimas kita - klausos? Pagaliau ar postmodernizmui išsiveržus už okuliarcentrizmo atsivers laisvos ir tolydžios sensorinès erdvès, ar tik iškils naujos hierarchijos? XXI a. pradžioje atgyjantis okuliarcentrizmo triumfas gali būti ir dar vienos jo rezignacijos prologas. Tikrovei tampant daugialype, susipinant kelioms ontologinèms jos sandaroms, virtualioms patirtims susiliejant su autentiškomis, tikètina, kad gali nepakakti iccentruoti vieną juslę. Jau XX a. pabaigoje, išsiplètus elektroninių mediju bei marketingo kuriamai naujai sensorinei erdvei, buvo itin daug diskutuota apie sinestezinio patyrimo vertę ir gebą suvokti bei veikti tokioje perkeistoje tikroveje. Gali būti, jog vis labiau technologijomis atakuojamas žmogaus sensoriumas nepajègs kurti monojuslinès paradigmos, veikiausiai tai bus dvinarè, trinare ar dar daugybiškesnè paradigminè ašis, leisianti apklausti ne tik istoriškai masyvų okuliarcentrizma, bet ir i kultūros paribius išstumtą sinestezini tvarumą. Jei pažvelgtume i sinestezijos sampratos formavimąsi iki XXI a. pradžios, iškiltų i̇domi, neatpažinta ir neįvertinta okuliarcentristinès ir neokuliarcentristinès sinestezijos dichotomija. Bet tai jau kito straipsnio tema.
Kitu juslių estetikos formavimosi procesai, atrodo, igalina ramų okuliarcentrizmo saulèlydi nepakeičiant jo kita sensorine galios struktūra. Herbertas Marcuse tvirtina, jog šiuo metu kultūrai reikalingi nauji jutimo būdai (Marcuse 1964: 165). Kaip matome, skirtingos filosofinio mąstymo kryptys suteka i̇ vieną deltą - naujos sensorinès būklès, naujo aisthesis būvio poreikị. Galime manyti, jog kitu jusliu estetikai ir teorijai tenka ne vien tik vaduotis iš klasikinès estetikos gniaužtu - ją savaip skatina beveik eschatologine išsisėmusių, ištuštejusiu jutimo ir aisthesis paradigmu trauka.

Vadinasi, okuliarcentrizmo tamsa gali tapti kitu jusliu estetikos priešaušriu, galios struktūrų sąlygota atskiru pojūčiu represija - alternatyviu ju pozicijų ir net jungčiu skatuliu. Nors pojūčiu hierarchijos konfliktuoja su kitu juslių estetikos galimybe, besirandanti nauja, galima sakyti, sinestezinè estetikos būklè iš esmès ateina užgesinti okuliarcentrizmo šviesą - anksčiau ar vèliau turètume pripažinti, kad vieno pojūčio estetika yra iš esmés negalima. Nors Vakaru estetika represyviai siekè itvirtinti okuliarcentristini modeli, paneigdama estetikos kaip tokios daugiapojūtiškuma, tiek meno praktikos, tiek estetinių teoriju paveldas rodo estetika kaip sudètingu manipuliaciju sistema siekiant dirbtinai atsiriboti nuo kitu pojūčiu dalyvavimo estetiniame patyrime. Menų sintezės idejja, ìvairiose epochose pasirodžiusi skirtingiausiais pavidalais, iš tiesų buvo kompromisinis regos galiu apribojimas ir pusiausvyros su potencialia sinestezijos estetika palaikymas.

Hierarchiniame Vakaru sensoriume neimanoma antitezė. Pasirodo, kad aukš- 


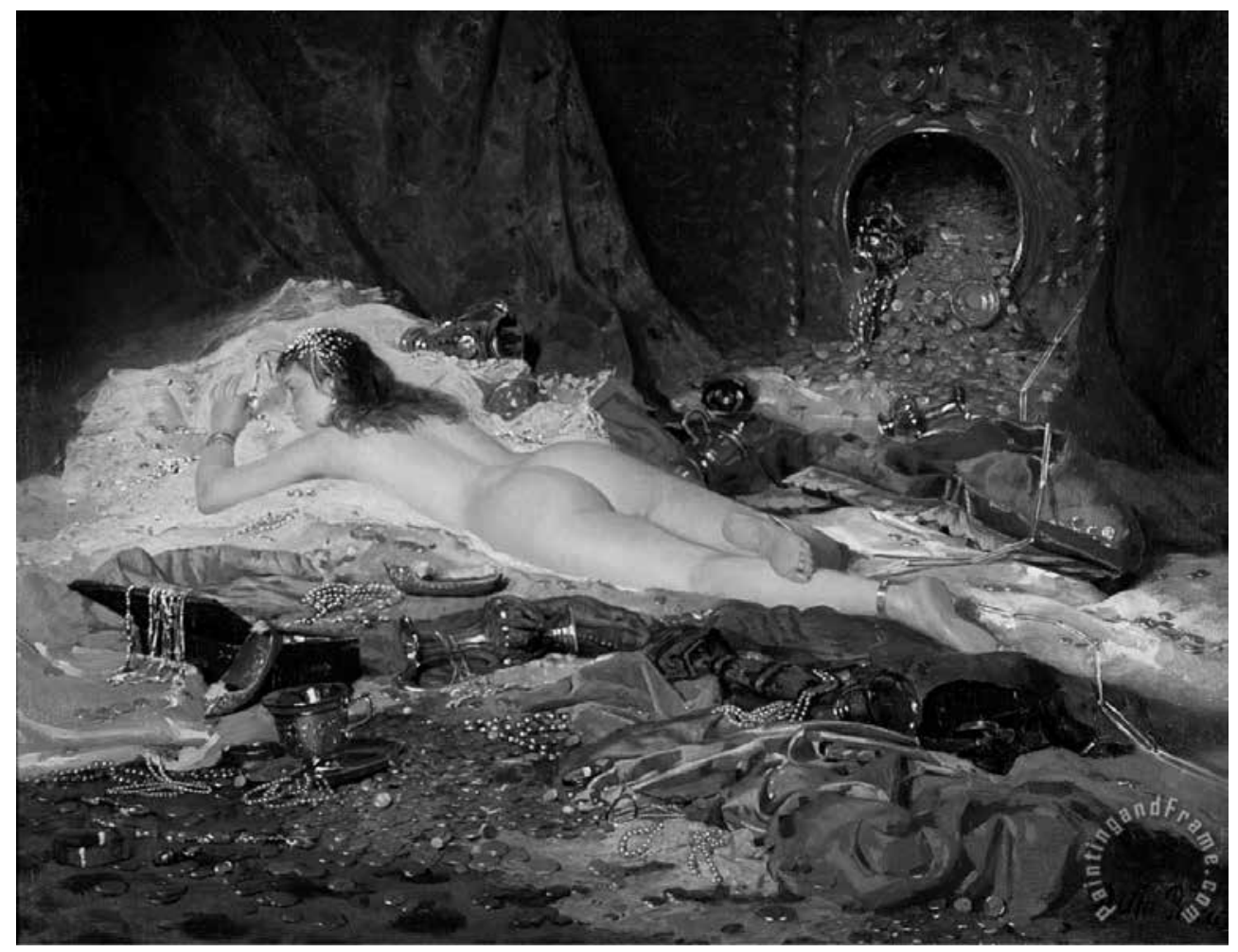

Della Rocca. Lobio gausybè, XIX a.

čiausiosios juslès - regos - neigimui nèra simetriškai žemiausio pojūčio. Nors žmogaus juslyne žioji aksiologinis plyšys, aukštesniuosius pojūčius skiriantis nuo žemesniujų, tačiau toks atskyrimas nėra nuoseklus. Aklumo metafora, beje, igijusi ypatingą reikšmę prancūzų filosofijoje ir veikianti kaip absoliučiojo regos pojūčio išnykimas, užtemdymas, iškelia kitus pojūčius, ypač lytèjima, kaip beveik lygiaverčiai pažintinius ir netgi estetinius. Taigi žmogiškasis pažinimas nėra tamsus, apšviečiamas vien tik regos institucine galia. Tai rodo, jog pačiuose regos hegemonijos pamatuose slūgso pojūčių universalumo, cikliškumo, netgi sąlyginio lygiavertiškumo užuomazgos, t. y. ištisas sinestezijos potencialas. Maža to, kitų juslių estetikos apraiškų istoriškai apčiuopiama pradžia kyla iš regos santykio su kitomis juslemis. Ir taip yra ne tik dèl to, kad rega užkelta i galios struktūrų viršūnę, bet ir todèl, kad šis, ilgainiui suabsoliutintas pojūtis nuolat yra ginčijamas kitų pojūčių. Rega tèra tik sąlyginis atskaitos taškas daugybiškoms jusliu jungtims. Kylant sinestezinio patyrimo bei jo struktūrinio dèmens meno kūriniuose poreikiui, rega pamažu paverčiama multisensorinių jungčių laidininku, tiesiog eiline sudedamaja multisensorinių sistemų dalimi.

Juvelyrinis dirbinys, tarpstantis tarp kūno juslyno intymumo, lytëjimo pojūčių, haptinių pojūčių ir akies arogantiškos ir šaltos distancijos - štai tokia būtų 
švytuoklè, jei filosofinès minties, susijusios su okuliarcentrizmu, judèjimo trajektoriją mėgintume nužymèti kintančiu santykiu su juvelyriniu lobynu, ypatinga grožio steigtimi, beje, esančia visose kultūrose nepriklausomai nuo epochos. Imdami Vakaru minties refleksyvumą jusliu ir, konkrečiai, akies atžvilgiu, galime pastebèti, kad juo sekuliaresnè darèsi mintis, juo neutralesnèn užuoglaudon patekdavo juvelyrinis lobynas, kuris lyg ir nesisiejo su kintančiu meno ir jusliu santykiu. Juvelyrinis lobynas ilgainiui tapo sekuliaraus, kasdienio pasaulio konstanta, kuri tik XX a. pabaigoje perėmè kitose meno šakose atsiradusi refleksyvuma, galiausiai apėmusi ir regos klausimą. Šiuolaikinis juvelyrinis lobynas nèra vien tik akies citadele, nors nuo 9-ojo dešimtmečio garbinamas vizualusis posūkis vis labiau pabrèžia meno reiškinius vizualumo kreidos ratu. Tačiau vèlgi galime patirti esant tą pati principą juo labiau esencializuojama rega, juo labiau kyla pasipriešinimas vienos juslès monopoliui. Dabartinis juvelyrinis dirbinys nèra patiriamas vien rega - galètume dristi kalbèti apie juvelyrikos mul- tisensoriškuma, jos sinestezija, taip pat galios ir distancijos isimbolinimo per juvelyrini dirbini paradoksalu nunykimą - nors deimantai vis dar nurodo socialinę hierarchiją, jie multisensoriniu patirčiu ir polivektorinių verčiu persmelktoje sąlygiškai nebetiesinëje erdvèje žvilga kitaip nei dvinarëje galingojo ir silpnojo patirties struktūroje. Regos kvestionavimas jau reiškia ir socialinę kritika, o juvelyrinio dirbinio apyvarta sociumo struktūrose jau nèra vienareikšmè. Nei karūna, nei ordinas nebėra tik stebejjimo objektas, steigiantis galią ir ją spinduliuojantis per vaizdą. Juvelyrinis brangumas vis dar išlieka mentaline galios ir turto hierachijos riba, tačiau policentrinèje regos plotmèje jis devalvuojasi: lygiai kaip Galileo Galilei XVI a. teigè norįs žinoti apie tuos vizualinius skirtumus, pagal kuriuos taip lengvai skiriama tikra nuo melagingo, - lygiai taip pat Debordo spektakliškos visuomenès vizualumo tvane vien rega darosi keblu pastebèti, tarkim, Svarovskio ir tikru brangakmeniu skirti. Grynasis, perteklinis vizualumas niveliuoja, naikina skirtumus, apakina ir paslepia.

\section{IŠVADOS}

Stebinantis, bet, matyt, dèsningas pastarąji dešimtmeti augantis istoriku dėmesys juslemms, siekimas jas įtraukti i praeities supratima, jusliu istorizavimas atveria pačios juslès talpumą ir galią. Greta regos hierarchines pozicijas besidalinančios kitos juslès kol kas yra tarsi neatverti kultūriniai masyvai, kitaip mūsu sensoriką centruojantys lobynai. Juk jau nebekelia abejoniu, jog modernusis sensoriumas iš tiesu yra daug sudètin- gesnis, sklidesnis ir heterogeniškesnis, nei tai leistų vakarietiškoji regos juslès hegemonija. Tačiau okuliarcentrizmas iš tiesų niekada nebuvo visiškai įsigalëjęs Vakaru mąstyme ir kultūroje, nes periodiškai kildavo abejojimo juo banga, nuo XIX a. pabaigos kartu su romantizmo mesta Apšvietos racionalizmui kritika igavusi per visą $X X$ a. milžinišką ir gana diferencijuotą jèga, ir galiausiai pasitikusi okuliarcentrizmo ivvairialypes ir stip- 
rias grižtis XXI a. pirmaisiais dešimtmečiais. Sisteminga okuliarcentrizmo kritika atitinkanti dabarties santyki su regos hierachine pozicija galime traktuoti kaip dideles apimties ir daugelio autoriu vykdyta mastymo eksperimenta, galiausiai regos prioriteto neigima traktuojant kaip viena iš paties okuliarcentrizmo aspektu. XX a. akies savineiga grižta i naujas XXI a. vizualumo apoteozes kaip tas pats autonomiškas ir suverenus visiocentrizmas. Straipsnio refrenu pasirinkta lobyno metafora kaip perteklinės akies provaizdis parodo oku-

\section{Literatūra ir nuorodos}

Bataille Georges. 2014. Historie de l'Oeil. Paris: Pauvert.

Baudrillard Jean. 1979. La séduction. Paris: Galilée. Breton André. 1987. Mad Love: 15, Caws M. A. (trans.). Lincoln: University of Nebraska Press.

Brook Isis. 2002. Experiencing Interiors: Ocularcentrism and Merleau Ponty's Redeeming of the Role of Vision: 69. Journal for British Society for Phenomenology, Vol. 33, No. 1.

Danto Arthur. 2003. The Abuse of Beauty: Aesthetics and the Concept of Art. Chicago and La Salle, Illinois: Open Court Publishing.

Derrida Jacques. 1978. Writing and Difference: 27. London: Routledge and Kegan Paul.

Descartes René. 1973. The Philosophical Works of Descartes: 148. Vol. 1. Cambridge: Cambridge University Press.

Eco Umberto. 1987. Arte e bellezza nell' estetica medievale. Milano: R.C.S. Libri \& Grandi Opere S.p.A.

Eco Umberto. 1997. Menas ir grožis viduramžiu kultūroje. Vertè Jonas Vilimas. Vilnius: Baltos lankos.

Foucault Michel. 2012. The Birth of the Clinic. London: Routledge.

Heidegger Martin. 1977. The Question Concerning Technology and Other Essays: 48. New York: Harper\&Row.

Horkheimer Max. 1978. Dawn and Decline: Notes 1926-1931 and 1950-1969: 162. New York: Stabury Press.

Howes David. 1991. Olfactum in Transition, How- liarcentrizmo i̇sisukimą circulus vitiosus jis visur: filosofijoje, estetikoje, socialinèje sandaroje. Kalbèti nereginčia kalba apie regos nesvarbumą neįmanoma ne tik dèl kultūrinès inercijos, net ir dèl pačios regos juslès dvilypumo - reginti ar apakinta (šviesa, auksu, ašmeniu), ikūnyta ar iškūnyta (greta kitų juslių ar monadinè), teorinè ar praktinè (proto ir optinè-receptorinè) rega yra vakarietiškosios sąmonès atvirumo būdas (nebūtinai, bet iš tiesų vienintelis), sujungiantis tikrovès sandus.

es D. (ed). The Varieties of Sensory Experience. Toronto: University of Toronto Press.

Howes David. 2010. Sensual Relations: Engaging the Senses in Culture and Social Theory. Michigan: University of Michigan Press.

Jay Martin. 1991. The Disenchantment of the Eye: Surrealism and the Crisis of Ocularcentrism. Visual Anthropology Review, Vol. 7, No. 1: 15, 17, $31,69$.

Jay Martin. 1993. Downcast Eyes: The Denigration of Vision in Twentieth-century French Thought. Berkeley: University of California Press.

Jonas Hans. 1966. The Nobility of Sight: A Study in the Phenomenology of the Senses, Jonas H. (ed.). The Phenomenon of Life: Towards a Philosophical Biology: 135-156. New York: Harper and Row.

Karavanagh Donncha. 2004. Ocularcentrism and its Others: A Framework for Metatheoretical Analysis, Organization Studies, Vol. 25, No. 3: 446. London, Thousand Oaks, CA\&New Delhi: SAGE Publications.

Levin David M. 1993. Modernity and the Hegemony of Vision (Levin D. M. ed.). Berkeley: University of California Press.

Marcuse Herbert. 1964. One-Dimensional Man: Studies in the Ideology of Advanced Industrial Society: 165. Boston: Baecon Press.

Merleau-Ponty Maurice. 1964. L'oeil et l'esprit. Paris: Gallimard.

Ong Walter. 1967. The Presence of the World: 74. New Haven: Yale University Press. 